\title{
Soil physico-hydraulic properties under organic conilon coffee intercropped with tree and fruit species
}

\author{
Gustavo Soares de Souza(1), Danielle Inácio Alves(2), Maurício Lima Dan(1), Julião Soares de Souza Lima(2), \\ Abner Luiz Castelão Campos da Fonseca(1), João Batista Silva Araújo(3) \\ and Lorena Abdalla de Oliveira Prata Guimarães ${ }^{(1)}$
}

\begin{abstract}
(1)Instituto Capixaba de Pesquisa, Assistência Técnica e Extensão Rural (Incaper), Fazenda Experimental Bananal do Norte, Rodovia ES-483, Pacotuba, CEP 29323-000 Cachoeiro de Itapemirim, ES, Brazil. E-mail: gustavo.souza@incaper.es.gov.br, mauricio.dan@incaper.es.gov.br, abner.fonseca@incaper.es.gov.br, lorena.prata@hotmail.com (2)Universidade Federal do Espírito Santo, Centro de Ciências Agrárias, Rua Alto Universitário, s/no, Guararema, CEP 29500-000 Alegre, ES, Brazil. E-mail: danielle.inacio@hotmail.com, limajss@yahoo.com.br (3)Incaper, Fazenda Experimental Mendes da Fonseca, Rodovia BR-262, Km 94, Fazenda do Estado, CEP 29375-000 Venda Nova do Imigrante, ES, Brazil. E-mail: araujojs@incaper.es.gov.br
\end{abstract}

\begin{abstract}
The objective of this work was to evaluate the cultivation effects of organic conilon coffee (Coffea canephora) intercropped with tree and fruit species on soil physico-hydraulic properties. Conilon coffee managements in the organic system were: T1, full-sun monoculture; T2, T3, T4, and T5, intercropping with peach palm (Bactris gasipae), gliricidia (Gliricidia sepium), banana (Musa sp.), and inga (Inga edulis), respectively; and T6, an area of secondary native forest used as a control. The evaluated soil physico-hydraulic properties were: bulk density, porosity, plant-available water capacity, soil-penetration resistance, soil-water content, soil temperature, and least limiting water range. Conilon coffee intercropped with peach palm and gliricidia resulted in lower soil bulk density and penetration resistance, and in higher total porosity, microporosity, and soil-water content. Organic coffee shaded with peach palm and gliricidia improve the soil physico-hydraulic quality, in comparison with the soil under monoculture in full sun and with the soil of secondary native forest.
\end{abstract}

Index terms: Bactris gasipae, Coffea canephora, Gliricidia sepium, climatic vulnerability, shade trees, shaded coffee.

\section{Atributos físico-hídricos do solo sob café conilon orgânico consorciado com espécies arbóreas e frutíferas}

\begin{abstract}
Resumo - O objetivo deste trabalho foi avaliar os efeitos do cultivo de cafeeiro conilon (Coffea canephora) orgânico consorciado com espécies arbóreas e frutíferas sobre os atributos físico-hídricos do solo. Os manejos do cafeeiro conilon, no sistema orgânico, foram: T1, monocultivo a pleno sol; T2, T3, T4 e T5, consórcios com pupunha (Bactris gasipae), gliricídia (Gliricidia sepium), banana (Musa sp.) e ingá (Inga edulis), respectivamente; e T6, uma área de mata nativa secundária utilizada como controle. Os atributos físicohídricos do solo avaliados foram: densidade, porosidade, capacidade de água disponível para as plantas, resistência à penetração, conteúdo de água, temperatura e intervalo hídrico ótimo do solo. Os consórcios de café conilon com pupunha e gliricídia resultaram em menores densidade do solo e resistência à penetração, e em maiores valores de porosidade total, microporosidade e conteúdo de água no solo. Cafezais orgânicos sombreados com pupunha e gliricídia melhoram a qualidade físico-hídrica do solo, em comparação ao solo com monocultivo a pleno sol e ao solo de mata secundária.
\end{abstract}

Termos para indexação: Bactris gasipae, Coffea canephora, Gliricidia sepium, vulnerabilidade climática, árvores para sombreamento, café sombreado.

\section{Introduction}

Coffee (Coffea spp.) is the most popular and consumed beverage in the world. The two most important economic species are arabica (C. arabica L.) and conilon (C. canephora Pierre ex A. Froehner). Conilon coffee is produced preferentially in tropical regions and in locations at less than 500-m altitude
(Ferrão et al., 2012). Brazil is the second largest producer of conilon coffee, with production distributed mainly in the states of Espírito Santo, Rondônia, and Bahia (Brasil, 2016).

Most Brazilian coffee is produced in monoculture under full sun. However, the adoption of monocultures has led to the depletion of agricultural soils in many regions, resulting in loss of fertility, organic matter, 
structure, and soil physical quality (Pérez Marin et al., 2006; Guimarães et al., 2014; Pinard et al., 2014; Silva et al., 2015). This degradation of soil structure changes the dynamics of water in the soil and reduces the agricultural productivity (Morais et al., 2006; Pinard et al., 2014; Souza et al., 2015).

In addition, current climate patterns tend to exhibit extreme events characterized mainly by the prolongation of droughts and rising temperatures, threatening agricultural productivity (Morais et al., 2006; Lin, 2007). Low-water availability to plants is mainly due to nonuniform rainfall distribution and unfavorable soil structure (Reynolds et al., 2008; Silva et al., 2015). Soil structure and soil-water content also affect the availability of oxygen and nutrients to plants, as well as root penetration (Reynolds et al., 2008; Souza et al., 2015). Soil-water availability can be an indicator of soil physical quality (Silva et al., 2014).

The management priorities of modern coffee crops should be focused on managing mechanisms that protect farmers from climate vulnerabilities (Morais et al., 2006; Lin, 2007; Araújo et al., 2015). The use of intercropping systems with shade trees is indicated as an adaptive strategy to extreme climatic events (Morais et al., 2006; Lin, 2010), with the use of crops of major economic interest partially shaded by tree or shrub species.

Partially shaded systems improve soil structure by enabling a greater water storage and availability (Morais et al., 2006; Guimarães et al., 2014; Padovan et al., 2015; Thomazini et al., 2015). The use of shade trees should also be considered because of their low cost, which makes it financially accessible to small farmers, in order to help them protect crops in rural areas (Lin, 2007, 2010). However, most of the reports on these systems address arabica coffee; thus, the available literature lacks conclusive information on conilon coffee.

The hypothesis of the present study is that organic conilon coffee intercropped with tree and fruit species, under Brazilian tropical conditions, improves the structural quality of the soil, which results in higher soil-water content compared to coffee managed in full sun.

The objective of this work was to evaluate the effect of organic conilon coffee plants intercropped with tree and fruit species on the soil physico-hydraulic properties.

\section{Materials and Methods}

The work was carried out at Fazenda Experimental Bananal do Norte - an experimental farm of Instituto Capixaba de Pesquisa, Assistência Técnica e Extensão Rural (Incaper) -, located in the municipality of Cachoeiro de Itapemirim, in the state of Espírito Santo, Brazil $\left(20^{\circ} 45^{\prime} \mathrm{S}, 41^{\circ} 47^{\prime} \mathrm{W}\right.$, at $146 \mathrm{~m}$ altitude). The soil of the area is a Neossolo Flúvico Tb eutrófico, according to the Brazilian soil classification system (Santos et al., 2013) (Table 1), with soft-undulated relief. The climate of the region is type Aw, according to KöppenGeiger's classification (Alvares et al., 2013), with an annual rainfall of $1,197 \mathrm{~mm}$, and an annual average temperature of $23.8^{\circ} \mathrm{C}$. The conilon coffee cultivar used was Emcaper 8151 - Robusta Tropical, which is propagated by seed.

The studied managements systems were: T1, conilon coffee in monoculture under full sun; T2, conilon coffee intercropped with peach palm (Bactris gasipaes Kunth); T3, conilon coffee intercropped with gliricidia [Gliricidia sepium (Jacq.) Kunth]; T4, conilon coffee intercropped with the banana (Musa sp.) cultivar BRS Japira (Pacovan); and T5, conilon coffee intercropped with inga (Inga edulis Mart.). An area of secondary native forest, Semideciduous Seasonal Forest (Atlantic Forest biome), close to the experiment, was used as control (T6). The coffee cultivation was conducted in an organic management, at $3.0 \times 1.0 \mathrm{~m}$ spacing. The intercropped species were planted in the coffee planting lines, at 3.0x6.0 m spacing. Each plot was composed of two lines, with 15 coffee plants and 4 intercropped plants, according to the management, except for the management in full sun. The area was left fallow for six years and, before that, it was used for growing corn, beans, and sorghum in rotation.

Conilon coffee and shade species were planted in the same period, in January 2013, in holes of $0.45 \mathrm{~m}$ diameter by $0.40 \mathrm{~m}$ depth, with a soil-boring machine coupled to the power take-off of a $4 \times 4$ tractor, with $78 \mathrm{HP}$ and $4,150 \mathrm{~kg}$ total mass. Supplementary irrigation was performed by applying a $10 \mathrm{~mm}$ water depth, at seven-day intervals, except for the harvest period. For the fertilization at planting of coffee and shade plants, $0.3 \mathrm{~kg}$ of reactive natural phosphate, $0.2 \mathrm{~kg}$ of limestone, and $10 \mathrm{~L}$ of chicken manure per hole were used. Two cover fertilizations were performed at 5 and $10 \mathrm{~L}$ per plant, as follows: the first one with chicken manure $[77 \%$ organic matter $(\mathrm{OM})$, 
$2.3 \% \mathrm{~N}, 0.85 \mathrm{~kg} \mathrm{dm}^{-3}$ density, and $25 \%$ humidity]; and the second one with organic compost of elephant grass and tanned bovine manure $(60.5 \% \mathrm{OM}, 1.5 \% \mathrm{~N}$, $0.14 \mathrm{~kg} \mathrm{dm}^{-3}$ density, and $46.3 \%$ humidity). The control of the invasive plants was carried out with mechanical weed cutter between the lines, activated in the power take-off of a 4x2 microtractor, with $15 \mathrm{HP}$ and $1,140 \mathrm{~kg}$ total mass; manual weeding was done in the plant lines.

Peach palm plants were conducted without the shoot thinning. The cutting of stems for palm heart extraction was performed when the first node was formed at the base of the plant. In March 2014, the first pruning was done for gliricidia and inga plants, which was conducted to form a canopy $4 \mathrm{~m}$ above the ground. In gliricidia, two more prunings were performed, in December 2014 and August 2015, the latter eliminated $100 \%$ of the canopy. In the plots of inga, two thinning prunings were performed during the same period of gliricidia's pruning. Banana plants were managed with four pseudostems per clump, in a staggered form.

Soil samples $(\mathrm{n}=96)$ were collected in April 2015, in $0.05 \times 0.05 \mathrm{~m}$ volumetric cylinders, in the area of projection of the aerial part, $0.50 \mathrm{~m}$ away from the planting line, at $0-0.1,0.1-0.2,0.2-0.4$, and $0.4-0.8 \mathrm{~m}$ soil depths, for the determination of soil bulk density, total porosity, microporosity, and macroporosity (Donagema et al., 2011). Soil-water retention was obtained in Richards' pressure chambers, using 6 , $10,33,100,500$, and $1.500 \mathrm{kPa}$ pressures with porous plates. Plant-available water capacity was obtained by the difference between field capacity $(\psi=10 \mathrm{kPa})$ and permanent wilting point $(\psi=1.500 \mathrm{kPa})$. Aeration porosity was obtained by the difference between total porosity and field capacity (Reynolds et al., 2008). Soilpenetration resistance was measured with an impact penetrometer (Stolf et al., 2005), in the same places where the soil was sampled with volumetric cylinders.
The least limiting water range was determined (Severiano et al., 2011; Silva et al., 2014; Souza et al., $2015)$. Soil-water content at field capacity $\left(\theta_{\mathrm{FC}}\right)$ or at airfilled porosity $\left(\theta_{\mathrm{AFP}} ; 0,10 \mathrm{~m}^{3} \mathrm{~m}^{-3}\right)$ was considered as the upper limit and soil-water content at permanent wilting point $\left(\theta_{\mathrm{PWP}}\right)$ or corresponding to a soil-penetration resistance of $2.5 \mathrm{MPa}\left(\theta_{\mathrm{SPR}}\right)$ was considered as the lower limit.

Soil volumetric water content $\left(\theta_{\mathrm{v}}\right)$ and soil temperature were also measured $(n=768)$, using a GS3 sensor (Decagon Devices, Pullman, WA, USA) at the same layers and sites from which samples were collected with volumetric cylinders. Soil-water content was estimated through dielectric permittivity, while temperature was recorded by a thermistor. Properties were measured between 7:30 and 8:30 h, within a single day, at the beginning of each month, from May to December 2015.

O'Brien's (O'Brien, 1992) and Shapiro-Wilk's (Shapiro \& Wilk, 1965) tests were applied at 5\% probability, in order to evaluate the homogeneity of the variances and the normality of the residues, respectively. Statistical analysis was performed using a completely randomized design, with four replicates, by the analysis of variance, and the means were compared by the Tukey's test, both at $5 \%$ probability.

\section{Results and Discussion}

The properties soil bulk density, macroporosity, and aeration porosity were affected by a significant interaction between managements and soil layers (Table 2).

Conilon coffee intercropped with peach palm and gliricidia showed lower soil bulk density and higher total porosity, at the four soil layers evaluated (Table 2). The managements in full sun and the intercroppings

Table 1. Chemical and granulometric characterization ${ }^{(1)}$ of the Neossolo Flúvico Tb eutrófico, prior to the deployment of treatments.

\begin{tabular}{|c|c|c|c|c|c|c|c|c|c|c|c|c|c|c|c|}
\hline Soil depth & $\mathrm{pH}$ & $\mathrm{P}$ & $\mathrm{K}$ & $\mathrm{Na}$ & $\mathrm{Ca}$ & $\mathrm{Mg}$ & $\mathrm{Al}$ & $\mathrm{H}+\mathrm{Al}$ & $\mathrm{SB}$ & ECEC & PCEC & SOM & Sand & Loam & Clay \\
\hline (m) & & ---- & $\mathrm{ng} \mathrm{dm}$ & ---- & --- & $---\cdot$ & - & $\operatorname{mol}_{\mathrm{c}} \mathrm{d}$ & --- & 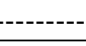 & 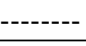 & $-\cdots$ & $---(g$ & 1)-- & --- \\
\hline $0.0-0.1$ & 6.1 & 20.6 & 121.6 & 18.7 & 3.5 & 1.2 & 0.0 & 2.0 & 5.2 & 5.2 & 7.2 & 18 & 492 & 120 & 388 \\
\hline $0.1-0.2$ & 5.4 & 5.5 & 50.7 & 17.7 & 2.3 & 0.6 & 0.1 & 2.6 & 3.2 & 3.3 & 5.8 & 12 & 476 & 127 & 397 \\
\hline $0.2-0.4$ & 5.3 & 2.8 & 36.8 & 18.1 & 2.0 & 0.4 & 0.2 & 2.5 & 2.6 & 2.7 & 5.0 & 9 & 452 & 147 & 401 \\
\hline $0.4-0.8$ & 5.7 & 4.0 & 24.3 & 13.9 & 1.9 & 0.4 & 0.0 & 1.5 & 2.4 & 2.4 & 3.9 & 5 & 400 & 128 & 471 \\
\hline
\end{tabular}

${ }^{(1)}$ Donagema et al. (2011). pH, potential of hydrogen; $\mathrm{P}$, phosphorus; $\mathrm{K}$, potassium; Na, sodium; Ca, calcium; Mg, magnesium; Al, aluminum; $\mathrm{H}+\mathrm{Al}$, potential acidity; SB, sum of bases; ECEC and PCEC, effective and potential cation-exchange capacity; SOM, soil organic matter. 
with banana and inga showed the highest values of soil bulk density, and the lowest values of total porosity. The secondary native forest had lower soil bulk density than the full sun treatment - up to a $0.4 \mathrm{~m}$ depth -, and a lower total porosity than the intercropping with peach palm and gliricidia.

The results of soil bulk density and total porosity in coffee intercropped with peach palm and gliricidia showed the improvement of the soil structure under these agroforestry systems, which was also observed by Guimarães et al. (2014). Coffee rooting in the management with tree and fruit species contributes to the improvement of soil structure, mainly due to the formation of biopores (Souza et al., 2015) that show connectivity and continuity greater than the structural pores, which favors the movement of soil solution and gases.

Conilon coffee intercropped with peach palm and gliricidia showed higher soil microporosity, indicating a greater potential for water storage, which is also reported by Lin (2007). Coffee managements and the secondary native forest did not differ as to their soil micropore values between the study layers (Table 2).

Table 2. Soil physico-hydraulic properties under organic conilon coffee (Coffea canephora) in full sun or intercropped with tree and fruit species and under a native forest at four soil depths ${ }^{(1)}$.

\begin{tabular}{|c|c|c|c|c|c|c|c|}
\hline \multirow{2}{*}{$\begin{array}{l}\text { Soil depth } \\
\text { (m) }\end{array}$} & \multirow[t]{2}{*}{ Full sun } & \multicolumn{4}{|c|}{ Intercropped with } & \multirow{2}{*}{$\begin{array}{c}\text { Secondary } \\
\text { native forest }\end{array}$} & \multirow[t]{2}{*}{ Mean } \\
\hline & & Peach palm & Gliricidia & Banana & Inga & & \\
\hline \multicolumn{8}{|c|}{ Soil bulk density $\left(\mathrm{kg} \mathrm{dm}^{-3}\right)$} \\
\hline $0.0-0.1$ & $1.40 \mathrm{Aa}$ & $1.12 \mathrm{Ab}$ & $1.23 \mathrm{Aab}$ & $1.34 \mathrm{Aa}$ & $1.38 \mathrm{Aa}$ & $1.22 \mathrm{Bab}$ & 1.28 \\
\hline $0.1-0.2$ & $1.43 \mathrm{Aa}$ & $1.14 \mathrm{Ab}$ & $1.22 \mathrm{Ab}$ & $1.45 \mathrm{Aa}$ & $1.43 \mathrm{Aa}$ & $1.33 \mathrm{ABab}$ & 1.33 \\
\hline $0.2-0.4$ & $1.44 \mathrm{Aa}$ & $1.07 \mathrm{Ac}$ & $1.16 \mathrm{Abc}$ & $1.42 \mathrm{Aa}$ & $1.34 \mathrm{Aab}$ & $1.18 \mathrm{Bbc}$ & 1.27 \\
\hline$\underline{0.4-0.8}$ & $1.39 \mathrm{Aa}$ & $1.15 \mathrm{Ab}$ & $1.17 \mathrm{Ab}$ & $1.45 \mathrm{Aa}$ & $1.43 \mathrm{Aa}$ & $1.43 \mathrm{Aa}$ & 1.33 \\
\hline Mean & 1.42 & 1.12 & 1.19 & 1.41 & 1.40 & 1.29 & - \\
\hline \multicolumn{8}{|c|}{ Total porosity $\left(\mathrm{m}^{3} \mathrm{~m}^{-3}\right)$} \\
\hline $0.0-0.1$ & 0.51 & 0.63 & 0.60 & 0.52 & 0.50 & 0.53 & $0.55 \mathrm{~A}$ \\
\hline $0.1-0.2$ & 0.50 & 0.60 & 0.58 & 0.47 & 0.49 & 0.49 & $0.54 \mathrm{~A}$ \\
\hline $0.2-0.4$ & 0.50 & 0.62 & 0.62 & 0.48 & 0.54 & 0.50 & $0.52 \mathrm{~A}$ \\
\hline $0.4-0.8$ & 0.52 & 0.61 & 0.58 & 0.48 & 0.46 & 0.45 & $0.52 \mathrm{~A}$ \\
\hline Mean & $0.52 b$ & $0.62 \mathrm{a}$ & $0.60 \mathrm{a}$ & $0.49 \mathrm{~b}$ & $0.50 \mathrm{~b}$ & $0.50 \mathrm{~b}$ & - \\
\hline \multicolumn{8}{|c|}{ Microporosity $\left(\mathrm{m}^{3} \mathrm{~m}^{-3}\right)$} \\
\hline $0.0-0.1$ & 0.39 & 0.49 & 0.49 & 0.40 & 0.37 & 0.33 & $0.41 \mathrm{~A}$ \\
\hline $0.1-0.2$ & 0.40 & 0.47 & 0.45 & 0.37 & 0.38 & 0.30 & $0.40 \mathrm{~A}$ \\
\hline $0.2-0.4$ & 0.38 & 0.47 & 0.46 & 0.37 & 0.43 & 0.30 & $0.40 \mathrm{~A}$ \\
\hline $0.4-0.8$ & 0.39 & 0.50 & 0.47 & 0.38 & 0.37 & 0.35 & $0.41 \mathrm{~A}$ \\
\hline Mean & $0.39 b$ & $0.49 \mathrm{a}$ & $0.46 \mathrm{a}$ & $0.38 \mathrm{~b}$ & $0.39 \mathrm{~b}$ & $0.32 \mathrm{~b}$ & - \\
\hline \multicolumn{8}{|c|}{ Macroporosity $\left(\mathrm{m}^{3} \mathrm{~m}^{-3}\right)$} \\
\hline $0.0-0.1$ & $0.12 \mathrm{Ab}$ & $0.14 \mathrm{Aab}$ & $0.11 \mathrm{Ab}$ & $0.12 \mathrm{Ab}$ & $0.13 \mathrm{Aab}$ & $0.21 \mathrm{Aa}$ & 0.14 \\
\hline $0.1-0.2$ & $0.10 \mathrm{Ab}$ & $0.13 \mathrm{Aab}$ & $0.13 \mathrm{Aab}$ & $0.10 \mathrm{Ab}$ & $0.11 \mathrm{Aab}$ & $0.19 \mathrm{Aa}$ & 0.13 \\
\hline $0.2-0.4$ & $0.12 \mathrm{Ab}$ & $0.15 \mathrm{Aab}$ & $0.16 \mathrm{Aab}$ & $0.12 \mathrm{Ab}$ & $0.11 \mathrm{Ab}$ & $0.20 \mathrm{Aa}$ & 0.14 \\
\hline $0.4-0.8$ & $0.13 \mathrm{Aa}$ & $0.12 \mathrm{Aa}$ & $0.12 \mathrm{Aa}$ & $0.10 \mathrm{Aa}$ & $0.09 \mathrm{Aa}$ & $0.10 \mathrm{Ba}$ & 0.11 \\
\hline Mean & 0.12 & 0.13 & 0.13 & 0.11 & 0.11 & 0.17 & - \\
\hline \multicolumn{8}{|c|}{ Aeration porosity $\left(\mathrm{m}^{3} \mathrm{~m}^{-3}\right)$} \\
\hline $0.0-0.1$ & $0.15 \mathrm{Ab}$ & $0.17 \mathrm{Ab}$ & $0.15 \mathrm{Ab}$ & $0.18 \mathrm{Ab}$ & $0.16 \mathrm{Ab}$ & $0.28 \mathrm{Aa}$ & 0.18 \\
\hline $0.1-0.2$ & $0.14 \mathrm{Ab}$ & $0.16 \mathrm{Ab}$ & $0.17 \mathrm{Ab}$ & $0.14 \mathrm{Ab}$ & $0.16 \mathrm{Ab}$ & $0.25 \mathrm{Aa}$ & 0.17 \\
\hline $0.2-0.4$ & $0.16 \mathrm{Ab}$ & $0.19 \mathrm{Aab}$ & $0.21 \mathrm{Aab}$ & $0.17 \mathrm{Ab}$ & $0.16 \mathrm{Ab}$ & $0.27 \mathrm{Aa}$ & 0.19 \\
\hline $0.4-0.8$ & $0.17 \mathrm{Aa}$ & $0.14 \mathrm{Aa}$ & $0.15 \mathrm{Aa}$ & $0.14 \mathrm{Aa}$ & $0.13 \mathrm{Aa}$ & $0.14 \mathrm{Ba}$ & 0.15 \\
\hline Mean & 0.16 & 0.17 & 0.17 & 0.16 & 0.15 & 0.23 & - \\
\hline \multicolumn{8}{|c|}{ Plant-available water capacity $\left(\mathrm{L} \mathrm{m}^{-3}\right)$} \\
\hline $0.0-0.1$ & 88.38 & 94.33 & 82.52 & 90.99 & 90.39 & 82.56 & $88.19 \mathrm{~A}$ \\
\hline $0.1-0.2$ & 82.33 & 85.73 & 89.86 & 85.70 & 85.30 & 61.92 & $81.81 \mathrm{AB}$ \\
\hline $0.2-0.4$ & 81.00 & 82.97 & 86.95 & 86.34 & 79.20 & 54.63 & $78.52 \mathrm{BC}$ \\
\hline $0.4-0.8$ & 74.36 & 82.28 & 72.05 & 66.17 & 70.86 & 56.23 & $70.32 \mathrm{C}$ \\
\hline Mean & $81.52 \mathrm{a}$ & $86.33 \mathrm{a}$ & $82.85 a$ & $82.30 \mathrm{a}$ & $81.44 \mathrm{a}$ & $63.84 \mathrm{a}$ & - \\
\hline
\end{tabular}

${ }^{(1)}$ Means followed by equal letters, uppercase in the columns and lowercase in the lines, do not differ by the Tukey's test, at $5 \%$ probability. 
The secondary native forest showed the highest values of macropores and soil aeration porosity, except for the $0.4-0.8 \mathrm{~m}$ soil depths (Table 2). The managements in full sun and the intercropped ones did not show significant difference for macroporosity and aeration porosity in the evaluated soil depths. An increase of soil aeration favors a higher evaporative rate of soil-water and influences the supply of water to the plants (Bittelli et al., 2008).

Conilon coffee managements and the secondary native forest showed similar values for plant-available water capacity (Table 2) considered as limiting for agricultural use, with values lower than $100 \mathrm{~L} \mathrm{~m}^{-3}$ (Reynolds et al., 2008). Coffee managements and the secondary native forest showed reduced plant-available water capacity with the increasing of depth, which is associated to the higher-organic matter content and to the greater root development in the superficial layer. Organic matter, besides influencing the formation and stability of aggregates, helps soil-water retention (Olness \& Archer, 2005).

The conilon coffee plants intercropped with peach palm and gliricidia showed lower soil-penetration resistance (Figure 1) at different soil depths; however, the values of this variable were higher than those observed by Palma et al. (2013) in coffee crops with manual and mechanized harvesting. At $0.0-0.2 \mathrm{~m}$ soil depths, the managements and the secondary native forest did not show significant difference for soilpenetration resistance. Conilon coffee in full sun and the native forest area showed the highest values of soil-penetration resistance at $0.25-0.65 \mathrm{~m}$ soil depths, resulting from a less structured soil, but mainly of a lower soil-water content. The history of land use with successive conventional tillage contributed to reduce soil-penetration resistance, in comparison to the soil under native forest. In addition, the lower soilwater content in native forest contributed to intensify this difference in relation to the conilon coffee managements (Figure 2).

In general, the soil-penetration resistance increased with depth, mainly at $0.35-0.55-\mathrm{m}$ soil depth. A slight soil compaction may increase water retention, due to a new arrangement of soil particles with smaller pores and greater capillarity (Silva et al., 2014; Souza et al., 2015). However, compacted soil layers, formed by anthropic or natural processes, with an internal resistance greater than the penetration force of the roots, can limit the root development of coffee plants, as reported by Padovan et al. (2015) and Silva et al. (2015).

The soil-penetration resistance showed a predominance of moderate (1.0-2.0 MPa) and high (2.0-4.0 MPa) classes, in the soil under coffee intercropped with peach palm, gliricidia, banana, and inga, while the soil under conilon coffee in full sun and under secondary native forest showed values within the very high class (4.0-8.0 MPa), according to the Soil Survey Staff (1993). It is worth mentioning that soil resistance to penetration was measured during a drought period, which tends to increase values in relation to a soil with a higher soil-water content (Silveira et al., 2010).

The conilon coffee intercropped with peach palm and gliricidia showed higher soil-water contents at all soil depths (Figure 2 A), which also occurred in six of the eight evaluations carried out from May to December 2015 (Figure 2 B). A higher soil-water content under shaded coffee plants was also observed by Morais et al. (2006) and Lin (2010). In intercropped systems, the accumulation of plant residues on the soil acts as a physical barrier, reducing evapotranspiration and improving soil infiltration and soil-water retention (Thomazini et al., 2015).

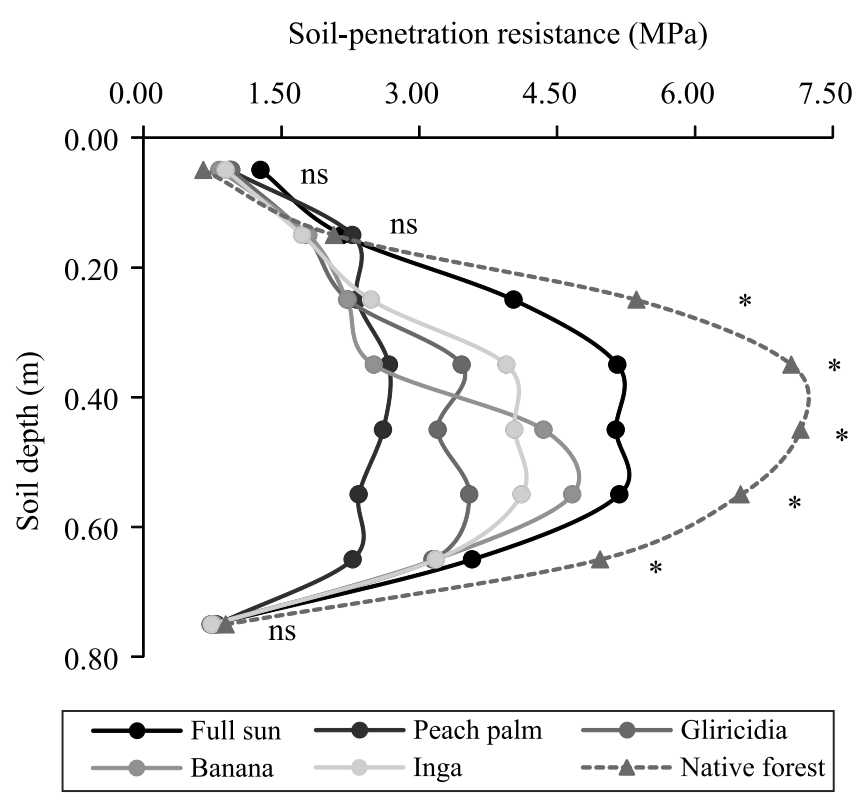

Figure 1. Soil-penetration resistance in organic conilon coffee (Coffea canephora) in full sun, or intercropped with peach palm (Bactris gasipae), gliricidia (Gliricidia sepium), banana (Musa sp.), and inga (Inga edulis), and in an area of secondary native forest, in the municipality of Cachoeiro de Itapemirim, ES, Brazil. *Significant by the Tukey's test, at $5 \%$ probability. ${ }^{\text {ns Nonsignificant. }}$ 
Although conilon coffee intercropped with peach palm and gliricidia favored soil-water content, the same fact did not occur for the management with banana and inga (Figure $2 \mathrm{~A}$ and $\mathrm{B}$ ), from May to December, due to the smaller volume of soil micropores. Drought periods, when there is less soilwater availability, as in August 2015 (Figure 2 B), tend to be more critical for coffee in intercropping systems, as tree species may show a higher capacity of water absorption, further reducing the water supply to coffee plants. However, pruning management of tree and fruit species can balance the intercropping and allow the joint development of species (Pérez Marin et al., 2006).

The native forest area had the lowest soil-water content, except for the $0.2-0.4 \mathrm{~m}$ depths, as well as the management of coffee in full sun. These lower values result from the absence of supplemental irrigation, and it was expected with the shading reduction (Lin, 2007), which led to a greater evaporation and coffee transpiration (Lin, 2010; Araújo et al., 2015). However, the higher-plant density in the forest, and the presence
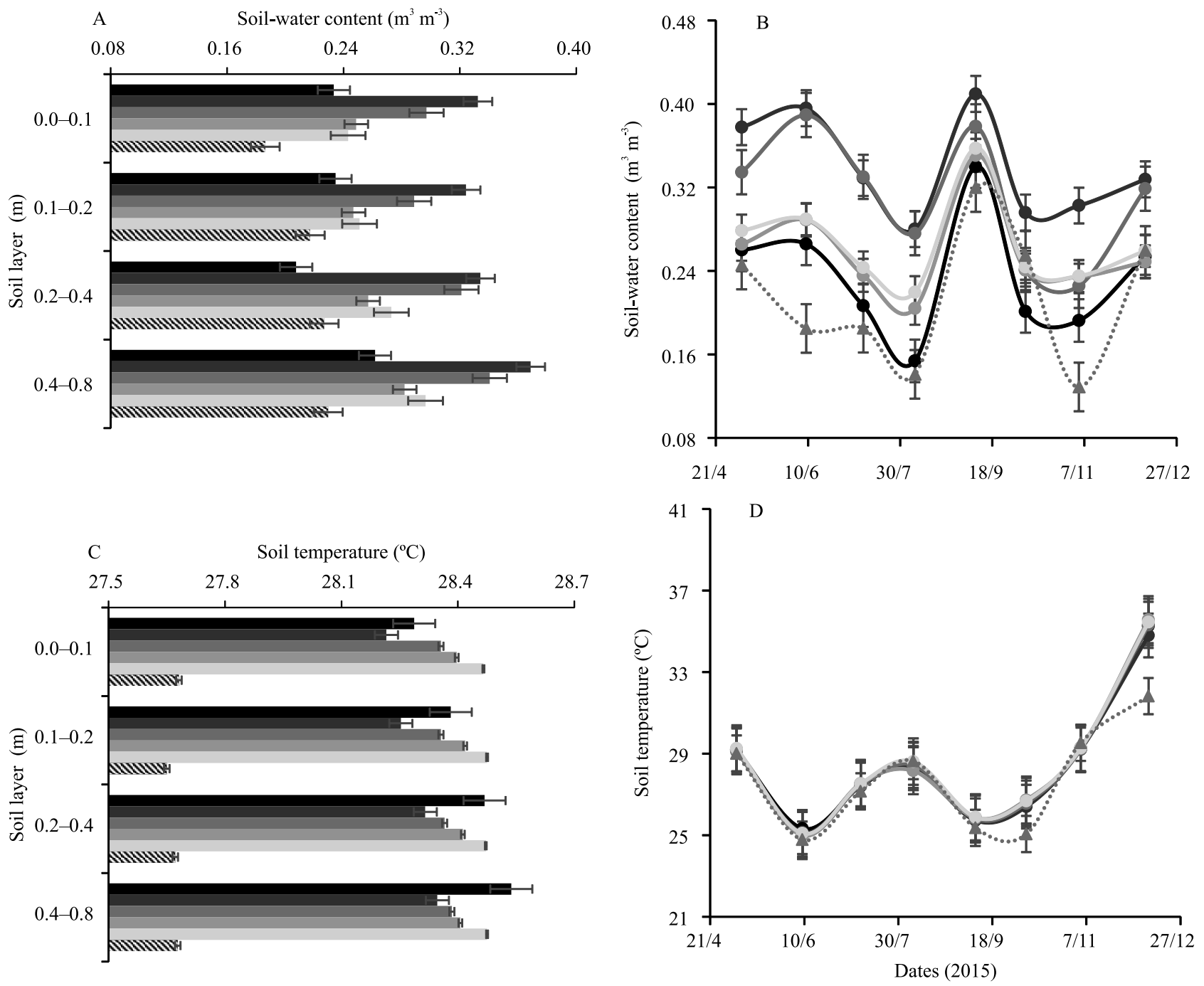

\begin{tabular}{|llllllll}
$\mathbf{a}_{\mathrm{T}}$ & $\mathbf{a}_{\mathrm{T} 2}$ & $\mathbf{\mathrm { T }} 3$ & $\mathrm{~T} 4$ & $\mathrm{~T} 5$ & $\mathbb{\mathrm { T }} 6$
\end{tabular}

$\longrightarrow \mathrm{T} 1 \multimap \mathrm{T} 2 \multimap \mathrm{T} 3 \longrightarrow \mathrm{T} 4 \longrightarrow \mathrm{T} 5 \cdots \cdots \mathrm{T} 6$

Figure 2. Soil-water content (A, B) and soil temperature (C, D) cultivated with organic conilon coffee (Coffea canephora) under full sun (T1), or intercropped with peach palm (Bactris gasipae) (T2), gliricidia (Gliricidia sepium) (T3), banana (Musa sp.) (T4), and inga (Inga edulis) (T5), and in an area with secondary native forest (T6), in the municipality of Cachoeiro de Itapemirim, ES, Brazil. Bars represent the standard error. 
of high-height plants (average canopy height was $20 \mathrm{~m}$ ) led to a higher soil-water demand at this site, which resulted in lower soil-water content.

The secondary native forest showed the lowest-soil temperatures at four soil depths (Figure $2 \mathrm{C}$ ) due to the greater shading that reduced the radiant energy inside the system, making the microclimate more pleasant, which was also verified by Lin (2010). Conilon coffee intercropped with inga showed a higher temperature $\left(28.5^{\circ} \mathrm{C}\right)$ in the $0-0.1$ and $0.1-0.2$ soil depths, which may be related to a greater activity of soil microorganisms in organic cultivation, while coffee in full sun showed the highest soil temperature $\left(28.5^{\circ} \mathrm{C}\right)$ at $0.2-0.4$ and $0.4-0.8 \mathrm{~m}$ soil depths, possibly as a consequence of the higher amount of radiation that reached the soil surface and propagated in depth. During the night, a greater soil surface cover, as in the intercropping treatments, may have reduced the soil energy loss through thermal radiation (Morais et al., 2006), which would have contributed to the maintenance of highersoil temperatures. The temporal amplitude of the soil temperature values $\left(24.8-31.8^{\circ} \mathrm{C}\right)$ was higher than the variation between the coffee managements and the forest $\left(27.7-28.5^{\circ} \mathrm{C}\right)$ (Figure $2 \mathrm{D}$ ), and this indicates a greater influence of the climate in comparison to the managements.

The conilon coffee intercropping with peach palm and gliricidia showed higher amplitudes of the least limiting water range (LLWR) (Figure $3 \mathrm{~B}$ and $3 \mathrm{C}$ ), which showed less physical restriction for

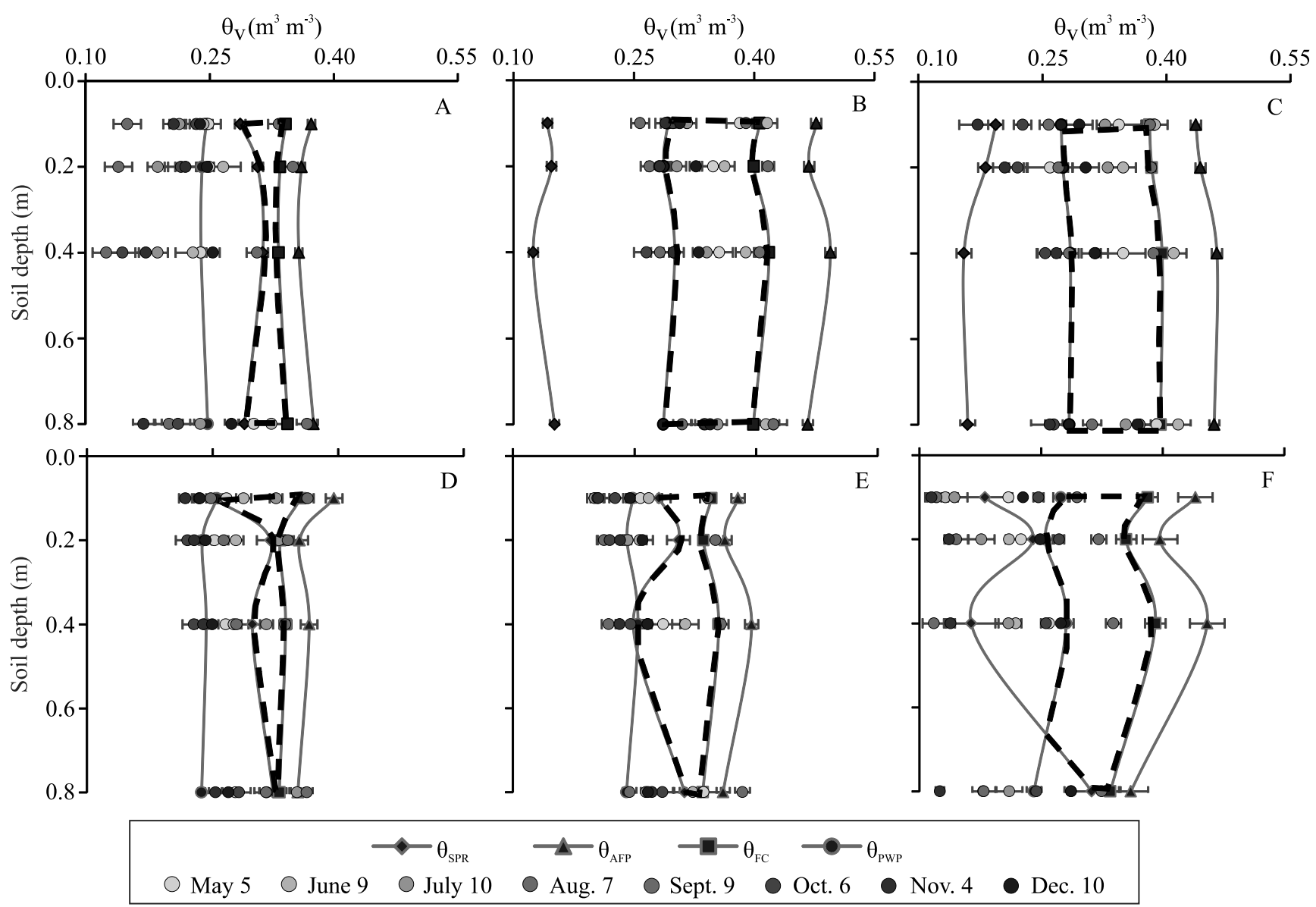

Figure 3. Volumetric water content of soil $\left(\theta_{\mathrm{v}}\right)$ cultivated with organic conilon coffee (Coffea canephora) in full sun (A), or intercropped with peach palm (Bactris gasipae) (B), gliricidia (Gliricidia sepium) (C), banana (Musa sp.) (D), and inga (Inga edulis) (E), and in secondary native forest (F), on May 5, June 9, July 10, August 7, September 9, October 6, November 4, and December 10 , and in the critical limits of soil-penetration resistance $\left(\theta_{\mathrm{SPR}}\right)$, permanent wilt point $\left(\theta_{\mathrm{PWP}}\right)$, field capacity $\left(\theta_{\mathrm{FC}}\right)$, and air-filled porosity $\left(\theta_{\mathrm{AFP}}\right)$, in the municipality of Cachoeiro de Itapemirim, ES, Brazil. Dotted black line indicates the least limiting water range. Bars represent the standard error. 
crop development. Peach palm and gliricidia plants, propagated by cuttings, showed a branched root system that contributed to the development of a soil structure with interconnected pores, favoring the movement of water and gases in the soil (Souza et al., 2015). Similar results occurred for the secondary forest, except for the $0.6-0.8 \mathrm{~m}$ soil depths (Figure $3 \mathrm{~F}$ ).

A smaller amplitude of LLWR occurred in the managements in full sun and in the intercropping with banana (Figure $3 \mathrm{~A}$ and D), due to the greater physical limitation imposed by the higher soil bulk density and lower soil-water retention. Similar result occurred for the intercropping with inga at $0-0.2$ and $0.6-0.8 \mathrm{~m}$ soil depths. No management showed LLWR $=0$ for the evaluated soil depths.

Coffee intercropped with peach palm and gliricidia had a longer evaluation period (50 and 59\%), with soilwater content between the LLWR boundaries $\left(\theta_{\mathrm{SPR}} \mathrm{e} /\right.$ ou $\theta_{\mathrm{PWP}} \leq \theta_{\mathrm{v}} \leq \theta_{\mathrm{AFP}}$ and/or $\left.\theta_{\mathrm{FC}}\right)$. The other managements and the native forest showed a predominance of soilwater content below the lower LLWR bound $\left(\theta_{\mathrm{v}} \leq \theta_{\mathrm{SPR}}\right.$ and/or $\theta_{\mathrm{PWP}}$ ), which indicates a limitation due to the high adsorption energy of water in the micropores, or to soil resistance to root penetration greater than the limit for coffee plant $(>2.5 \mathrm{MPa})$, or even to both causes.

The planting of partially shaded conilon coffee is technically feasible to protect the crop from climatic extremes, and should be considered as a potential adaptive strategy for farmers.

\section{Conclusion}

Organic conilon coffee (Coffea canephora) intercropped with peach palm (Bactris gasipae) and gliricidia (Gliricidia sepium) improves the soil physico-hydraulic quality, in comparison with the management in full sun and with the secondary native forest area, as these managements provide lower soil bulk density and soil-penetration resistance, as well as greater total porosity, microporosity, and soil-water content at $0.8 \mathrm{~m}$ depth.

\section{Acknowledgments}

To Conselho Nacional de Desenvolvimento Científico e Tecnológico (CNPq), for financial support; and to the employees of the Fazenda Experimental
Bananal do Norte, and of the Soil Laboratory of Fazenda Experimental Linhares, for technical support.

\section{References}

ALVARES, C.A.; STAPE, J.L.; SENTELHAS, P.C.; GONÇALVES, J.L. de M.; SPAROVEK, G. Köppen's climate classification map for Brazil. Meteorologische Zeitschrift, v.22, p.711-728, 2013. DOI: 10.1127/0941-2948/2013/0507.

ARAÚJO, A.V.; PARTELLI, F.L.; OLIVEIRA, M.G.; PEZZOPANE, J.R.M.; FALQUETO, A.R.; CAVATTE, P.C. Microclima e crescimento vegetativo do café conilon consorciado com bananeiras. Coffee Science, v.10, p.214-222, 2015.

BITTELLI, A.M.; VENTURA, F.; CAMPBELL, G.S.; SNYDER, R.L.; GALLEGATI, F.; PISA, P.R. Coupling of heat, water vapor, and liquid water fluxes to compute evaporation in bare soils. Journal of Hydrology, v.362, p.191-205, 2008. DOI: 10.1016/j. jhydrol.2008.08.014.

BRASIL. Ministério da Agricultura, Pecuária e Abastecimento. Culturas: café. Available at: <http://www.agricultura.gov.br/ vegetal/culturas/cafe/saiba-mais>. Accessed on: Aug. 222016.

DONAGEMA, G.K.; CAMPOS, D.V.B. de; CALDERANO, S.B.; TEIXEIRA, W.G.; VIANA, J.H.M. (Org.). Manual de métodos de análise de solo. 2.ed. rev. Rio de Janeiro: Embrapa Solos, 2011. 225p. (Embrapa Solos. Documentos, 132).

FERRÃO, R.G.; FONSECA, A.F.A. da; FERRÃO, M.A.G.; VERDIN FILHO, A.C.; VOLPI, P.S.; DE MUNER, L.H.; LANI, J.A.; PREZOTTI, L.C.; VENTURA, J.A.; MARTINS, D. dos S.; MAURI, A.L.; MARQUES, E.M.G.; ZUCATELI, F. Café Conilon: técnicas de produção com variedades melhoradas. 4.ed. rev. e ampl. Vitória: Incaper, 2012. 74p. (Incaper. Circular técnica, $\left.\mathrm{n}^{\mathrm{o}} 03-\mathrm{I}\right)$.

GUIMARÃES, G.P.; MENDONÇA, E. de S.; PASSOS, R.R.; ANDRADE, F.V. Soil aggregation and organic carbon of oxisols under coffee in agroforestry systems. Revista Brasileira de Ciência do Solo, v.38, p.278-287, 2014. DOI: 10.1590/S010006832014000100028 .

LIN, B.B. Agroforestry management as an adaptive strategy against potential microclimate extremes in coffee agriculture. Agricultural and Forest Meteorology, v.144, p.85-94, 2007. DOI: 10.1016/j.agrformet.2006.12.009.

LIN, B.B. The role of agroforestry in reducing water loss through soil evaporation and crop transpiration in coffee agroecosystems. Agricultural and Forest Meteorology, v.150, p.510-518, 2010. DOI: 10.1016/j.agrformet.2009.11.010.

MORAIS, H.; CARAMORI, P.H.; RIBEIRO, A.M. de A.; GOMES, J.C.; KOGUISHI, M.S. Microclimatic characterization and productivity of coffee plants grown under shade of pigeon pea in Southern Brazil. Pesquisa Agropecuária Brasileira, v.41, p.763-770, 2006. DOI: 10.1590/S0100-204X2006000500007.

O'BRIEN, P.C. Robust procedures for testing equality of covariance matrices. Biometrics, v.48, p.819-827, 1992. DOI: $10.2307 / 2532347$. 
OLNESS, A.; ARCHER, D. Effect of organic carbon on available water in soil. Soil Science, v.170, p.90-101, 2005. DOI: 10.1097/00010694-200502000-00002.

PADOVAN, M.P.; CORTEZ, V.J.; NAVARRETE, L.F.; NAVARRETE, E.D.; DEFFNER, A.C.; CENTENO, L.G.; MUNGUÍA, R.; BARRIOS, M.; VÍLCHEZ-MENDOZA, J.S.; VEGA-JARQUÍN, C.; COSTA, A.N.; BROOK, R.M.; RAPIDEL, B. Root distribution and water use in coffee shaded with Tabebuia rosea Bertol. and Simarouba glauca DC. compared to full sun coffee in sub-optimal environmental conditions. Agroforestry Systems, v.89, p.857-868, 2015. DOI: 10.1007/s10457-015-9820-z.

PALMA, M.A.Z.; VOLPATO, C.E.S.; SILVA, F.C. da; SOUZA, P. de; SILVA, J.A. Resistência do solo à penetração em cafezais cultivados com sistema mecanizado e manual. Coffee Science, v.8, p.364-370, 2013.

PÉREZ MARIN, A.M.; MENEZES, R.S.C.; SILVA, E.D.; SAMPAIO, E.V. de S.B. Efeito da Gliricidia sepium sobre nutrientes do solo, microclima e produtividade do milho em sistema agroflorestal no agreste paraibano. Revista Brasileira de Ciência do Solo, v.30, p.555-564, 2006. DOI: 10.1590/S010006832006000300015.

PINARD, F.; BOFFA, J.M.; RWAKAGARA, E. Scattered shade trees improve low-input smallholder Arabica coffee productivity in the Northern Lake Kivu region of Rwanda. Agroforestry Systems, v.88, p.707-718, 2014. DOI: 10.1007/s10457-014-9712-7.

REYNOLDS, W.D.; DRURY, C.F.; YANG, X.M.; TAN, C.S. Optimal soil physical quality inferred through structural regression and parameter interactions. Geoderma, v.146, p.466474, 2008. DOI: 10.1016/j.geoderma.2008.06.017.

SANTOS, H.G. dos; JACOMINE, P.K.T.; ANJOS, L.H.C. dos; OLIVEIRA, V.A. de; LUMBRERAS, J.F.; COELHO, M.R.; ALMEIDA, J.A. de; CUNHA, T.J.F.; OLIVEIRA, J.B. de. Sistema brasileiro de classificação de solos. 3.ed. rev. e ampl. Brasília: Embrapa, 2013. 353p.

SEVERIANO, E. da C.; OLIVEIRA, G.C. de; DIAS JÚNIOR, M. de S.; COSTA, K.A. de P.; SILVA, F.G.; FERREIRA FILHO, S.M. Structural changes in latosols of the Cerrado region: Irelationships between soil physical properties and least limiting water range. Revista Brasileira de Ciência do Solo, v.35, p.773782, 2011. DOI: 10.1590/S0100-06832011000300013.

SHAPIRO, S.S.; WILK, M.B. An analysis of variance test for normality (complete samples). Biometrika, v.52, p.591-611, 1965. DOI: $10.1093 /$ biomet/52.3-4.591.

SILVA, B.M.; OLIVEIRA, G.C.; SERAFIM, M.E.; SILVA, E.A.; FERREIRA, M.M. NORTON, L.D.; CURI, N. Critical soil moisture range for a coffee crop in an oxidic latosol as affected by soil management. Soil and Tillage Research, v.154, p.103-113, 2015. DOI: 10.1016/j.still.2015.06.013.

SILVA, J.F.G.; SEVERIANO, E. da C.; COSTA, K.A. de P.; BENITES, V. de M.; GUIMARÃES JÚNNYOR, W. da S.; BENTO, J.C. Chemical and physical-hydric characterisation of a Red Latosol after five years of management during the summer between-crop season. Revista Brasileira de Ciência do Solo, v.38, p.1576-1586, 2014. DOI: 10.1590/S0100-06832014000500023.

SILVEIRA, D. de C.; MELO FILHO, J.F. de; SACRAMENTO, J.A.A.S. do; SILVEIRA, E.C.P. Relação umidade versus resistência à penetração para um Argissolo Amarelo distrocoeso no Recôncavo da Bahia. Revista Brasileira de Ciência do Solo, v.34, p.659-667, 2010. DOI: 10.1590/S0100-06832010000300007.

SOIL SURVEY STAFF. Soil survey manual. Washington: USDA, 1993. (Agriculture Handbook 180).

SOUZA, G.S. de; SOUZA, Z.M. de; COOPER, M.; TORMENA, C.A. Controlled traffic and soil physical quality of an Oxisol under sugarcane cultivation. Scientia Agricola, v.72, p.270-277, 2015. DOI: 10.1590/0103-9016-2014-0078.

STOLF, R.; REICHARDT, K.; VAZ, C.P.M. Response to "Comments on 'Simultaneous Measurement of Soil Penetration Resistance and Water Content with a Combined PenetrometerTDR Moisture Probe' and 'A Dynamic Cone Penetrometer for Measuring Soil Penetration Resistance"'. Soil Science Society of America Journal, v.69, p.927-929, 2005. DOI: 10.2136/ sssaj2005.0927.

THOMAZINI, A.; MENDONÇA, E.S.; CARDOSO, I.M.; GARBIN, M.L. SOC dynamics and soil quality index of agroforestry systems in the Atlantic Rainforest of Brazil. Geoderma Regional, v.5, p.15-24, 2015. DOI: 10.1016/j. geodrs.2015.02.003.

$\overline{\text { Received on June 8, } 2016 \text { and accepted on September 14, } 2016}$ 